\title{
P339: Situational analysis of patient safety and risk management in healthcare settings in Benin
}

\author{
A Attolou Gbohoun*, L Assogba, E Beheton, IE Adisso, AD Gazard \\ From 2nd International Conference on Prevention and Infection Control (ICPIC 2013) \\ Geneva, Switzerland. 25-28 June 2013
}

\section{Introduction}

Patient safety is a priority for public health policies promoted by the WHO at the international level. It participates in the proper management strategies to strengthen national health systems, now recognized as a prerequisite for the success of any health program. According to WHO estimates, $4-16 \%$ of hospitalized patients suffer adverse effects and $75 \%$ of these can be avoided.

\section{Objectives}

Make an inventory of patient safety from the perspective of developing the main lines of the national strategy on patient safety and risk management and better care in Benin.

\section{Methods}

This is a cross-sectional study referred evaluative oneday patient safety, risk management and health vigilance in 39 hospitals in Benin. The hardware consists of a questionnaire whose items are divided into nine components of the strategy of the World Health Organization. The scores of items were multiplied by 20. A Quote> $60 \%$ expressed an acceptable safety and security $<40 \%$ unacceptable.

\section{Results}

Strengths: Existence of a directorate of hospital hygiene focused on the prevention of healthcare associated infections (69.4\%), the existence of regulations to prevent nosocomial infections (95.6\%), the existence of a best practices guide for health professionals $(74.4 \%)$, the existence of procedures on hand hygiene (71.08\%).

Weaknesses: Lack of national patient safety policy $(20 \%)$, lack of a social security system for health professionals against health care-related accidents (11.4\%),

Health Ministry of Benin, Cotonou, Benin lack of a funding mechanism for the consequences of health care-related accidents (06.2\%), organization of open days on patient safety and error reporting procedures related to care $(19.06 \%)$.

\section{Conclusion}

The analysis of the patient safety situation in Benin showed that results are obtained in some domains. However, many gaps remain. More strategies need to be implemented to ensure patient safety in Benin.

\section{Disclosure of interest}

None declared.

Published: 20 June 2013

doi:10.1186/2047-2994-2-S1-P339

Cite this article as: Attolou Gbohoun et al:: P339: Situational analysis of patient safety and risk management in healthcare settings in Benin. Antimicrobial Resistance and Infection Control 2013 2(Suppl 1):P339.

Submit your next manuscript to BioMed Central and take full advantage of:

- Convenient online submission

- Thorough peer review

- No space constraints or color figure charges

- Immediate publication on acceptance

- Inclusion in PubMed, CAS, Scopus and Google Scholar

- Research which is freely available for redistribution

\section{Biomed Central}

(c) 2013 Attolou Gbohoun et al; licensee BioMed Central Ltd. This is an Open Access article distributed under the terms of the Creative Commons Attribution License (http://creativecommons.org/licenses/by/2.0), which permits unrestricted use, distribution, and reproduction in any medium, provided the original work is properly cited. 